\title{
EFEKTIVITAS COGNITIVE BEHAVIOR ART THERAPY UNTUK MENINGKATKAN SELF-ESTEEM REMAJA OBESITAS YANG MENJADI KORBAN PERUNDUNGAN
}

\author{
Fadila Nisa UI Hasanah, Ihsana Sabriani Borualogo , Hedi Wahyudi \\ Universitas Islam Bandung \\ fadilanisaa@gmail.com
}

\begin{abstract}
ABSTRAK
Remaja obesitas kerap menjadi korban perundungan. Self-esteem mereka yang rendah, menghambat mereka untuk dapat adaptif dengan lingkungannya, sehingga menjadi rentan untuk menjadi korban perundungan. Penelitian ini bertujuan utuk mengukur efektivitas pemberian Cognitive Behavior Art Therapy guna meningkatkan self-esteem remaja obesitas yang menjadi korban perundungan. Teknik intervensi yang digunakan yaitu Cognitive Behavior Art Therapy yang diadaptasi dengan menggunakan panduan art therapy tecniques and application. Melalui intervensi ini, subjek mengeksplorasi emosi dan kebutuhannya, serta melakukan restrukturisasi kognitif pikiran negatif dan mengubahnya menjadi pikiran positif menggunakan media menggambar, agar mereka dapat adaptif dengan lingkungannya. Partisipan dalam penelitian ini adalah dua orang remaja obesitas korban perundungan yang mengalami kendala untuk dapat adaptif dengan lingkungannya, keduanya perempuan usia 15 tahun. Desain penelitian yang digunakan adalah one group pre-test post-test. Hasil penelitian dibahas secara deskriptif. Self-esteem diukur menggunakan Coopersmith Self-esteem Inventory. Analisis data dilakukan secara deskriptif dengan menghitung kenaikan skor self-esteem sampel dan membahasnya secara deskriptif pada tiap sampel berdasarkan data kuantitatif dan kualitatif yang ada. Pengukuran self-esteem sebelum dan sesudah intervensi menunjukkan bahwa Cognitive Behavior Art Therapy cukup efektif dalam meningkatkan selfesteem kedua remaja obesitas korban bully tersebut. Subjek pertama mengalami peningkatan skor selfesteem sebesar 42,31\%; sedangkan subjek kedua mengalami peningkatan skor self-esteem sebesar $38,46 \%$. Dengan meningkatnya self-esteem, remaja obesitas korban perundungan menjadi lebih mampu mengenali kelebihan dan kekurangan dirinya, memberikan penilaian positif mengenai dirinya, sehingga dapat adaptif dengan lingkungannya.
\end{abstract}

Kata kunci : Cognitive Behavior Art Therapy, Self-esteem, Obesitas, Korban perundungan

\begin{abstract}
Obese youth are often being bullied by people. Their low self-esteem inhibit themselves to adapt to the environment, and it makes them vulnerable to be bullied by people. The aim of this study was to measure the effectiveness of Cognitive Behavior Art Therapy to improve the self-esteem on obese youth who are victims of bullying. Cognitive Behavior Art Therapy was used as the iintervention techniques to improve selfesteem. The Cognitive Behavior Art Therapy was adapted by using the guide art therapy techniques and application. Through this intervention, subjects explored their emotions and needs, as well as cognitive restructuring, so the negative thoughts restructered into positive thoughts using drawing media. Therefore, they can expressed their feelings and needs, and hopefully they will be able to adapt to their environment. Participants in this study were two obese youth who are victims of bullying. They are suffering from obstacles to adapt to their environment, both are girls aged 15 years old. The research design was one group pre-test post-test. The results of the research are discussed descriptively, because the number of participants is only two persons, not sufficient to be tested hypothetically. Self-esteem was measured using Coopersmith Self-esteem Inventory. The data analysis was done descriptively by calculating the increase of self eteem score of the sample and review itu descriptively on each sample based on the quantitative and qualitative data that available. Measurements of self-esteem before and after intervention show that Cognitive Behavior Art Therapy is quite effective on improving the self-esteem of both obese youth who are victims of bullying. The first subject experienced an increase in self-esteem score of $42.31 \%$; While the second subject experienced an increase in self-esteem score of $38.46 \%$. With the improvement of selfesteem, the obese youth are able to recognize their own strengths and weaknesses, giving a positive assessment of themselves, so that they are able to adapt to the environment.
\end{abstract}

Keywords : Cognitive Behavior Art Therapy, Self-esteem, Obesity, Bullied Victims 


\section{Journal of Psychological Science and Profesion (JPSP)}

Vol.1, No.1, Desember 2017

E-mail: jpsp@unpad.ac.id

\section{PENDAHULUAN}

Salah satu masalah yang terjadi pada remaja dan berhubungan dengan penampilan adalah masalah kegemukan. Kegemukan sendiri terdiri dari dua kategori, yaitu kelebihan berat badan tingkat ringan (overweight) dan kelebihan berat badan tingkat berat (obesitas). Obesitas merupakan suatu kelainan atau penyakit yang ditandai oleh penimbunan jaringan lemak dalam tubuh secara berlebihan (Sarafino, 2002).

Obesitas merupakan permasalah global yang melanda masyarakat dunia termasuk Indonesia, hal ini disebabkan oleh perubahan gaya hidup masyarakat sekarang ini. Direktur Bina Gizi Masyarakat Kementerian Kesehatan (Kemenkes) dr Minarto menuturkan dua hal penyebab meningkatnya angka prevalensi obesitas di Indonesia, yaitu pola makan tidak seimbang dan aktivitas fisik yang rendah (http://www.republika.co.id).

Berdasarkan data dari World Health Organization (WHO), kasus obesitas di seluruh dunia bertambah lebih dari dua kali lipat sejak 1980. Pada tahun 2008 lebih dari 200 juta orang laki-laki dan hampir 300 juta orang perempuan mengalami obesitas (http://Intisari-Online.com). Jurnal medis Lancet merilis daftar negara-negara dengan tingkat obesitas tertinggi di dunia dan Indonesia berada di peringkat $10 \quad$ (2014) (http://www.bbc.com).

Hasil Riset kesehatan dasar (Riskesdas) Departemen Kesehatan RI 2013 menunjukkan bahwa prevalensi obesitas sentral di Indonesia meningkat dari $18,8 \%$ pada tahun 2007 menjadi $26,6 \%$ pada tahun 2013. Prevalensi gizi lebih secara nasional pada remaja umur 13-15 tahun di Indonesia sebesar 10,8\%, terdiri dari 8,3\% gemuk dan $2,5 \%$ sangat gemuk atau obesitas. Prevalensi gizi lebih pada remaja umur 16-18 tahun mengalami peningkatan yang signifikan dari tahun 2007 sebesar $1,4 \%$ menjadi $7,3 \%$ pada tahun 2013 (Kemenkes, 2013).

Obesitas tidak hanya menimbulkan masalah kesehatan namun juga menimbulkan masalah psikologis. Seoseorang yang mengalami kegemukan cenderung dijauhi oleh temantemannya.Terkadang seseorang dengan resiko kegemukan menjadi korban perundungan verbal. Karakteristik fisik seperti tinggi dan berat badan serta atribut yang melekat pada tubuh adalah sesuatu yang mudah ditangkap mata dan dijadikan sebagai ciri dari seseorang. Tampilan fisik yang berbeda dari kebanyakan orang, seringkali digunakan sebagai bahan untuk mengejek seseorang. Berbagai penelitian (eg, Psunder, 2010; Taylor 2011; Cash \& Pruzinsky, 2002) menunjukkan bahwa perundungan sering terjadi pada anak dengan tampilan fisik yang berbeda, misalnya anak yang mengalami obesitas. Mengucilkan ataupun mengejek seseorang berdasarkan karakteristik fisik orang tersebut juga merupakan contoh tindakan perundungan.

Menurut penelitian Schacter (1971) orang yang mengalami obesitas cenderung lebih sensitif dalam berinteraksi dibandingkan dengan orang yang tidak mengalami obesitas. Penelitian Bray (1976) dan Brownell (1981) juga menyebutkan bahwa orang yang mengalami obesitas mempunyai dampak buruk pada kesehatan dan interaksi sosial yang berlangsung selama rentang usia anak-anak hingga dewasa (Siregar, 2006). Perlakuan terhadap remaja obesitas seperti mengejek, mentertawakan, mengganggu, mempermainkan dan sebagainya juga menyebabkan remaja yang mengalami obesitas semakin menarik diri dari pergaulan dan aktivitas, sehingga mengganggu perkembangan sosialnya. Oleh karena itu, seringkali seseorang dengan resiko obesitas mengalami depresi, rasa putus asa, kurang percaya diri, pendiam, tersinggung, merasa tersisih dan menjauh dari kehidupan sosial serta resiko bulimia. Seseorang dengan kegemukan ini akan dianggap menjadi orang yang mudah tersinggung dan susah dalam bergaul.

Biasanya pihak yang menjadi target perundungan atau korban adalah pihak yang lebih lemah daripada pihak yang melakukan tindahakan perundungan. Pada remaja yang mengalami perundungan akibat tampilan fisiknya, berbagai bentuk tindakan perundungan yang dialami dapat ditangkap sebagai feedback mengenai penampilan fisik, persepsi akan bagaimana orang lain memandang dirinya, memicu pemikiran serta perasaan individu terhadap penampilan fisiknya, dan mempengeruhi self-esteem (Cash \& Pruzinsky, 2002).

Pada dasarnya, kemampuan untuk beradaptasi atau menyesuaikan diri dengan lingkungan sekitar seperti teman, tetangga saudara merupakan suatu hal yang amat menentukan bagi perkembangan seorang remaja. Bila remaja obesitas memiliki rasa percaya diri yang tinggi maka hal itu dapat membantu dirinya dalam menyesuaikan diri dengan keadaan sekitarnya menjadi lebih baik.

Orang yang memiliki self esteem rendah biasanya memiliki kesejahteraan psikologis yang 


\title{
Journal of Psychological Science and Profesion (JPSP)
}

\author{
Vol.1, No.1, Desember 2017
}

E-mail: jpsp@unpad.ac.id

rendah pula. la akan memperlakukan dirinya dan orang lain dengan cara-cara buruk (Emler, 2001), sehingga berpotensi untuk mengalami masalahmasalah fisik, mental, dan emosional (Kernis, 2003). Harga diri seseorang juga akan menentukan bagaimana dia akan menampilkan dirinya di lingkungannya (Oktavianti, Novia, Rahmawati, 2008). Subjek dengan self esteem rendah cenderung menampilkan perilaku yang tidak adaptif di lingkungannya.

Rendahnya self esteem dalam diri individu dimulai dari adanya pengalaman negatif dalam hidupnya. Bila individu banyak mengalami pengalaman negatif di masa awal kehidupannya, yaitu saat masa anak atau remaja, maka kemungkinan besar individu tersebut akan mengembangkan keyakinan diri yang negatif. Pola interaksi antara keyakinan, pemikiran, perilaku, dan emosi akan mempengaruhi cara individu memproses informasi yang diberikan lingkungan kepadanya. Proses informasi yang dilakukan individu dengan self-esteem rendah cenderung bias, dimana individu akan lebih memberikan perhatian dan mengingat pengalaman yang sesuai dengan keyakinan negatifnya dan melewatkan pengalaman yang sebenarnya dapat menantang keyakinan negatif tersebut (Fennel \& Jenkins, 2004).

Menurut Fennel (1998), esensi dari self esteem rendah ada pada keyakinan dasar atau core belief individu yang negatif secara global tentang dirinya ("me as a person"). Ketika penilaian individu terhadap dirinya sendiri negatif (misalnya "saya tidak berharga", "saya tidak cukup baik"), maka konsekuensi yang terjadi adalah munculnya self esteem yang rendah.

Cognitive Behavioral Art Therapy (CBAT) merupakan kombinasi dari dua terapi, yaitu Cognitive Behavioral Therapy dan Art Therapy. CBAT merupakan salah satu bentuk terapi yang menggunakan menggambar sebagai medianya dan Cognitive Behavioral Therapy sebagai pendekatannya. Secara konseptual, menggambar adalah serangkaian kegiatan yang dilakukan menggunakan media gambar, dimana klien dapat menyampaikan keadaan pikiran dan perasaannya terlepas dari pengaruh lingkungan, tanpa ada keterpaksaan ataupun merasa tertekan (Oster \& Crone,2004; Rubin, 2001).

Cognitive Behavioral Art Therapy adalah bentuk terapi di mana klien terlibat dalam cara berpikir tentang masalah mereka. Klien dapat mempersepsikan masalah mereka dari perspektif baru melalui gambar dan sadar terhadap perasaan dan pikirannya (Alavinezhad, et al., 2014; Malchiodi, 2003). Orang yang memiliki harga diri rendah seringkali kurang memiliki kemampuan dalam mengekspresikan dirinya dengan baik. Hal itu dikarenakan ia memiliki persepsi negatif terhadap dirinya sendiri, cemas dan takut dalam mengekspresikan pikiran dan perasaannya, dan merasa dirinya tidak mampu. Dalam penelitian ini, teknik menggambar dipilih peneliti dikarenakan, selain pengadministrasiannya yang mudah, juga karena termasuk terapi yang bersahabat (less threatening), dapat mengungkap aspek psikologis yang lebih spesifik (provide focused discussion), menawarkan pemecahan masalah yang kreatif (supply creative solutions), dapat memvisualisasikan masalah yang dihadapi (provide visual representations of problem areas), dan meningkatkan keterlibatan klien dalam proses terapi (expand therapeutic engagement) (Oster, \& Crone, 2004). Intevensi terhadap self esteem dengan pendekatan CBAT menuntut remaja obesitas menyadari proses yang membuat keyakinan negatif ini berlanjut, termasuk cara pemrosesan informasi dan maladaptive behavior terbentuk, serta mempelajari cara untuk mengatasinya melalui media menggambar.

\section{METODE}

Rancangan penelitian ini adalah quasi eksperimen dengan menggunakan one group pretest post-test design. Subjek penelitian ini adalah dua orang remaja perempuan usia 15 tahun, memiliki indeks massa tubuh di atas 27, dan sering mengalami perundungan oleh lingkungannya. Teknik sampling yang digunakan adalah purposive sampling. Karena jumlah sampel hanya dua orang, maka tidak dapat dilakukan uji hipotesis. Data yang diperoleh bersifat kuantitatif dan kualitatif. Data kuantitatif adalah berupa perhitungan skor self-esteem sebelum dan sesudah intervensi. Data kualitatif adalah berupa hasil wawancara dan observasi terhadap kedua sampel selama proses intervensi dilakukan. Analisis data dilakukan secara deskriptif dengan menghitung kenaikan skor selfesteem sampel dan membahasnya secara deskriptif pada tiap sampel berdasarkan data kuantitatif dan kualitatif tersebut.

Pada tahap awal penelitian, dilakukan wawancara terhadap kedua orang sampel untuk mendapatkan data mendetail mengenai riwayat obesitasnya, permasalahan self-esteem yang mereka alami, serta pengalaman perundungan yang sering mereka terima dari teman-teman di lingkungannya. 


\section{Journal of Psychological Science and Profesion (JPSP)}

Vol.1, No.1, Desember 2017

E-mail: jpsp@unpad.ac.id

Pada tahap pre-test, tingkat self-esteem kedua subjek penelitian diukur menggunakan Coopersmith Self-esteem Inventory. Kategorisasi skor self-esteem dibuat berdasarkan rentang interval, di mana skor 1-26 termasuk kategori rendah, sedangkan skor 27-52 termasuk kategori tinggi. Hasil pengukuran menunjukkan bahwa keduanya memiliki tingkat self-esteem yang rendah, yaitu skor 20 pada subjek pertama, dan skor 21 pada subjek kedua.

Intervensi diberikan menggunakan teknik Cognitive Behavioral Art Therapy (CBAT). Dalam intervensi ini peneliti berperan sebagai terapis, disupervisi oleh ahli Art Therapy dan ahli Cognitive Behavior Therapy. Proses intervensi dilakukan secara berkelompok. Peneliti menyusun modul intervensi berdasarkan hasil adaptasi peneliti dari buku Art Therapy Techniques and Applications (Buchalter, 2009).

Intervensi dilakukan menjadi tiga tahap, yaitu (1) psikoedukasi, (2) proses terapi, dan (3) terminasi. Proses terapi terdiri dari 8 sesi (pertemuan), di mana pertemuan dilaksanakan dua kali seminggu, dengan durasi 90 menit pada setiap pertemuan. Adapun delapan sesi intervensi terdiri dari kegiatan-kegiatan berikut ini, yaitu: (1) Stop Sign, (2) Saying No, (3) Counting Blessing, (4) Transformation, (5) Relationship, (6) Who Smiled At Me?, (7) Positive/Negative, (8) Cognitive Distortions and Positive Thinking.

Pada sesi Stop Sign, Subjek diminta untuk menggambar tanda berhenti (stop) dan taruh sesuatu yang dianggap menjadi penghambat baginya di tanda tersebut. Diskusi megenai apa yang membuat subjek terhambat dalam masalah emosi, hubungan sosial, atau dalam pencapaian tujuannya.

Pada sesi Saying No, subjek diminta menulis kata "NO" dengan ukuran cukup besar. Dan kelilingi kata "NO" dengan gambar yang merepresentasikan kekuatan, kekuasaan, dan kontrol. Diskusikan bagaimana cara mengatakan "NO" akan meningkatkan self-esteem dan perkembangan psikis yang lebih baik.

Pada Sesi Counting Blessing, tanyakan pada subjek seberapa sering mereka fokus pada anugerah yang mereka terima daripada masalah dan kesulitan yang mereka hadapi. Kemudian subjek diarahkan untuk memikirkan mengenai halhal positif dalam kehidupannya dan menggambarkan anugerah dari tuhan yang telah mereka dapatkan. Diskusikan bagaimana satu anugerah itu dapat membantu individu mengatasi masalah, kesulitan, dan stress yang dihadapi.

Pada sesi Transformation, subjek diminta untuk membuat "gambaran dirinya yang tidak menarik atau berkesan negatif" dan harus mengubahnya menjadi gambaran diri yang menarik dan berkesan positif. Diskusi berfokus pada pemeriksaan gambar transformasi dan menghubungkannya pada gaya hidup yang sehat seperti merubah pikiran negatif menjadi pikiran positif dan merubah perilaku yang tidak diinginkan menjadi lebih positif.

Pada sesi Relationship, telah disediakan "stick figure" untuk subjek. Subjek diminta untuk melengkapi gambar tersebut (wajah, rambut, pakaian, dll). Lalu masih dalam kertas yang sama, subjek diminta untuk menuliskan karakteristik yang dilihat dari seseorang yang mereka sukai untuk pertemanan. Diskusikan bagaimana pertemanan yang ideal bagi subjek. Realistiskah pertemanan tersebut? Eksplorasi cara yang mungkin dapat dilakukan untuk mencapai hal tersebut.

Pada sesi Who Smiled At Me? Subjek diminta untuk menggambar dirinya apa adanya. Lalu gambarlah orang yang sering tersenyum padamu dan tidak pernah mengganggumu. Diskusi fokus pada siapa saja orang yang tersenyum pada subjek dan mengarahkan subjek untuk lebih fokus pada mereka yang tersenyum padanya dibandingkan dengan yang sering mengganggunya.

Pada sesi Positive/Negative, subjek diminta menggambar bentuk oval atau outline wajah mereka dan membaginya menjadi dua bagian (kiri dan kanan). Minta subjek untuk menggunakan warna, gambar, dan tulisan untuk merepresentasikan pikiran positif di bagian wajah sebelah kanan, dan pikiran negative di bagian wajah sebelah kiri. Diskusi fokus pada gambar yang telah dibuat. Eksplorasi bagian wajah mana yang lebih dominan, reaksi subjek terhadap representasi pikiran mereka, dan perasaan serta sikap mereka.

Terakhir pada sesi Cognitive Distortions and Positive Thinking, setelah mengetahui pikiran otomatis negatif klien, tulis pikiran otomatis tersebut di atas kertas. Lalu minta klien untuk menggambarkan hal yang menjadi kebalikan dari pikiran otomatis tersebut. Diskusi fokus pada transformasi pikiran otamatis negatif yang dirubah menjadi gambar yang lebih positif dan subjek bereaksi akan hal tersebut.

Tiap kegiatan memiliki tujuan tersendiri, dalam upaya membantu sampel agar dapat melihat kelebihan dan kekurangan dirinya, menerima keadaan dirinya, sehingga mereka dapat adaptif dengan kondisi tubuhnya yang obesitas. Setelah selesai dilaksanakan intervensi, kemudian dilakukan kembali pengukuran skor 


\section{Journal of Psychological Science and Profesion (JPSP)}

Vol.1, No.1, Desember 2017

E-mail: jpsp@unpad.ac.id

self-esteem kedua sampel. Dengan demikian, dapat dihitung terjadinya peningkatan skor selfesteem pada kedua sampel, dengan membandingkan skor sebelum dan sesudah intervensi dilakukan.

\section{HASIL DAN PEMBAHASAN}

Subjek dalam penelitian ini berjumlah dua orang remaja obesitas yang bersedia mengikuti sesi terapi. Adapun identitas diri dari kedua subjek ini adalah sebagai berikut:

Tabel 1 .Data Subjek Penelitian

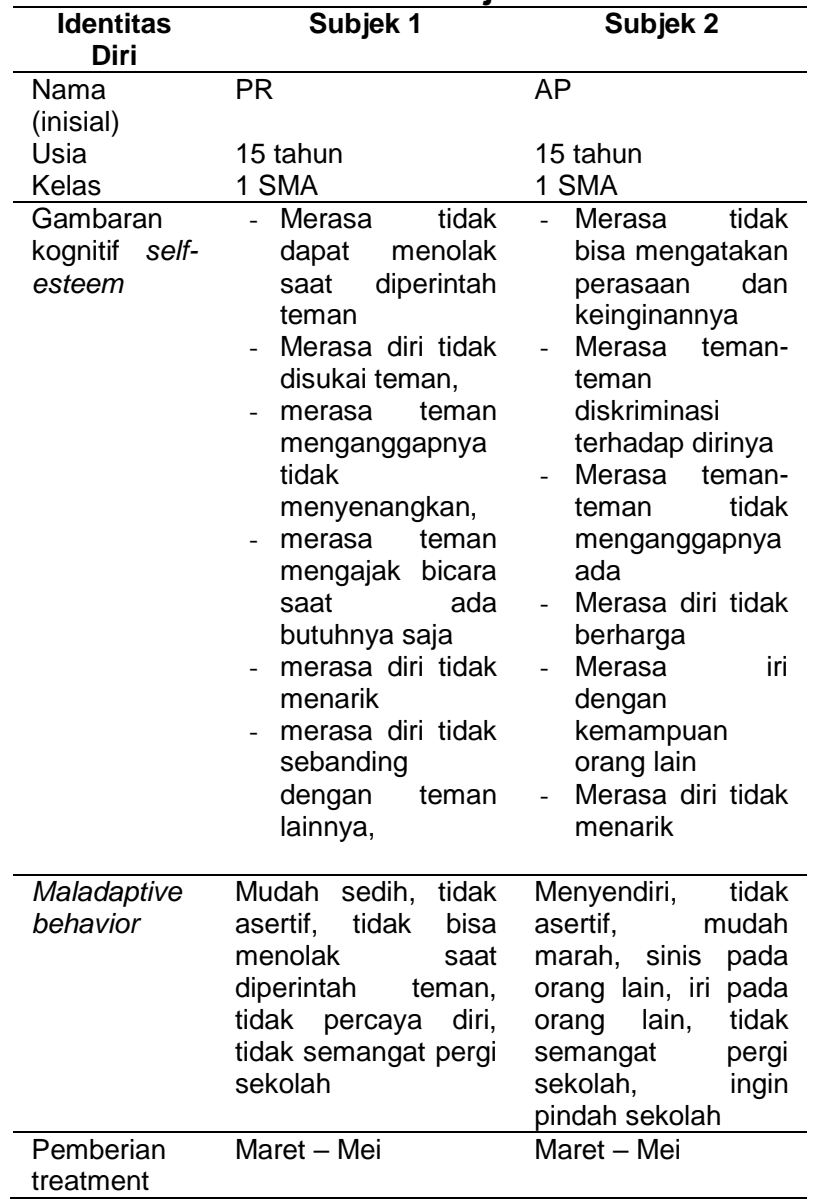

Di bawah ini akan dipaparkan mengenai hasil dari pengukuran self esteem dari tiap subjek sebelum dan sesudah diberikan intervensi CBAT. Adapun hasilnya adalah sebagai berikut:

Tabel 2. Hasil Pengukuran Skor Selfesteem Tiap Subjek

\begin{tabular}{cccccc}
\hline Subjek & $\begin{array}{c}\text { Skor } \\
\text { Pretest } \\
\text { Self- } \\
\text { esteem }\end{array}$ & Kategori & $\begin{array}{c}\text { Skor } \\
\text { Posttest } \\
\text { Self- } \\
\text { esteem }\end{array}$ & Kategori & $\begin{array}{c}\text { Persentase } \\
\text { Perubahan }\end{array}$ \\
\hline Subjek PR & 20 & Rendah & 42 & Tinggi & $42.31 \%$ \\
Subjek AP & 21 & Rendah & 41 & Tinggi & $38.46 \%$ \\
\hline
\end{tabular}

Berdasarkan tabel 2 di atas, dapat dilihat bahwa persentase perubahan skor self-esteem subjek PR sebesar 42.31\%, sedangkan persentase perubahan skor self-esteem subjek AP sebesar $38.46 \%$. Artinya, derajat self-esteem pada subjek PR dan Subjek AP mengalami peningkatan setelah diberikan intervensi Cognitive Behavioral Art Therapy (CBAT). Peningkatan derajat self-esteem kedua remaja obesitas ini terjadi setelah diberikan intervensi CBAT yang dirancang secara khusus untuk remaja obesitas sehingga mampu meningkatkan self-esteem mereka.

Self-esteem merupakan evaluasi yang dibuat oleh individu mengenai hal-hal yang berkaitan dengan dirinya yang diekspresikan melalui suatu bentuk penilaian setuju dan menunjukkan tingkat dimana individu meyakini drinya sebagai individu yang mampu, penting dan berharga (Coopersmith, 1967). Menurut Fennel (1998), esensi dari self-esteem rendah ada pada keyakinan dasar atau core belief individu yang negatif secara global tentang dirinya ("me as a person"). Ketika penilaian individu terhadap dirinya sendiri negatif, maka konsekuensi yang terjadi adalah munculnya self-esteem yang rendah.

Cognitive Behavior Art Therapy (CBAT) yang dijadikan intervensi dalam penelitian ini bertujuan untuk menentang pikiran yang salah (distorsi kognitif) dengan cara menampilkan buktibukti yang bertentangan dengan keyakinan mereka terhadap masalah yang sedang dihadapinya, kemudian membantu klien menyadari pikiran-pikiran otomatisnya (automatic thoughts), dan belajar untuk mempertanyakan, mengevaluasi, serta memperbaikinya dengan cara menggantinya dengan pikiran dan asumsi yang lebih positif dengan menggunakan mediamedia seni.

Gambar atau image dapat menjadi kendaraan bagi individu untuk melakukan refleksi, komunikasi, insight, dan pertumbuhan ke arah yang lebih matang (Buchalter, 2009; Oster \& Crone, 2004). Dengan membuat karya seni yang sangat jelas, maka sistem limbic akan merespon hal tersebut seperti hal yang nyata. Oleh karena itu, dengan membuat gambaran jelas mengenai hal positif dalam diri akan membuat individu tersebut meyakini hal positif tersebut lebih tampak nyata dan mampu menyakinkan dirinya untuk berubah menjadi lebih positif pula (Cohen, 2003).

Pada proses intervensi ini, kedua subjek belajar untuk melakukan eksplorasi mengenai emosi dan kebutuhan yang dimiliki. Hal ini dilakukan untuk mempermudah dalam 


\section{Journal of Psychological Science and Profesion (JPSP)}

Vol.1, No.1, Desember 2017

E-mail: jpsp@unpad.ac.id

mengeksplorasi masalah-masalah yang dihadapi dan juga dilakukan sebagai engagement untuk proses selanjutnya yaitu menguji pikiran otomatis negatif. Pikiran negatif yang muncul dalam suatu situasi diubah menjadi pikiran yang lebih positif menggunakan media menggambar.

Proses restrukturisasi kognitif dapat meningkatkan aktivitas otak bagian frontal cortex (proses top down) sehingga remaja obesitas akan mampu berpikir lebih rasional. Oleh karena itu, aktivitas sub-cortical amygdala-hippocampus (proses bottom up) akan menurun karena mereka akan mampu untuk mereduksi respon emosional dan meregulasi keadaan emosional negatif yang dialami saat menghadapi situasi yang tidak diinginkan (Clark \& Beck, 2010).

Pada tahap eksplorasi dan release emosi, terdapat beberapa kegiatan menggambar, diantaranya adalah: (1) Stop Sign, subjek belajar untuk menggali hal-hal yang menghambat diri. Dengan memahami hambatan yang dirasakan, harapannya akan lebih mudah dan mengerti cara untuk megatasinya. (2) Counting Blessing, subjek melakukan eksplorasi mengenai anugerah yang dimiliki. Dengan bersyukur atas anugerah yang dimiliki dapat membantu individu mengatasi masalah, kesulitan, dan stress yang dihadapi. (3) Relationship, subjek melakukan eksplorasi mengenai kebutuhan akan lingkungan pertemanan. Dengan eksplorasi mengenai hal ini, maka subjek akan mampu melihat kebutuhan pertemanan yang dimiliki ideal atau tidak dan pertemanan yang diinginkan realistis atau tidak. (4) Positive/Negative, subjek melakukan eksplorasi mengenai mood, perasaan, juga sikap mengenai diri. Dengan mengetahui pikiran, perasaan, dan sikap kalian dominan pada hal negatif atau positif akan meningkatkan kesadaran mengenai diri sendiri.

Kegiatan restrukturisasi kognitif dilakukan dengan beberapa kegiatan disputing pikiran otomatis negatif, diantaranya adalah (1) Saying No, subjek belajar menantang pikiran otomatis negative mengenai ketidakberdayaan di dalam dirinya. Dengan mengatakan "NO", subjek berusaha untuk melakukan penolakan terhadap perilaku negatif dari teman-teman dan mengontrol perilaku orang lain terhadap dirinya. (2) Transformation, subjek belajar menantang pikiran negative mengenai diri yang tidak menarik. Dengan mengubah gambaran diri yang menjadi lebih positif, maka subjek akan melihat bahwa dirinya (baik itu pikiran, penampilan, dan perilaku) dapat diubah menjadi lebih positif. (3) Who Smiled at Me, subjek belajar menantang pikiran negatif mengenai lingkungan. Subjek belajar untuk fokus pada siapa saja orang yang tersenyum padanya dibandingkan dengan yang sering mengganggunya. (4) Cognitive Distortions and Positive Thinking, subjek diajarkan untuk mengidentifikasi pikiran negatif dan mengubahnya menjadi pikiran yang lebih positif sehingga akan mampu meningkatkan harga dirinya. Tugas rumah juga diberikan setiap disputing pikiran otomatis negatif dilakukan dengan tujuan mempertahankan pemikiran positif yang telah dibangun.

Dengan adanya peningkatan skor selfesteem pada kedua subjek, artinya interevensi Cognitive Behavior Art Therapy mempunyai kontribusi dalam peningkatan self-esteem remaja obesitas dan dapat dikatakan memiliki efektivitas yang cukup tinggi.

\section{Hasil Pengukuran SkorAspek-Aspek Self- esteem Tiap Subjek Penelitian}

\section{Subjek PR}

Tabel 3. Perubahan Skor AspekSelf-esteem Subjek PR

\begin{tabular}{lccc}
\hline \multicolumn{1}{c}{ Aspek } & & & \multicolumn{2}{c}{ Pre-test } \\
& Skor & $\%$ & Kriteria \\
\hline Power & 4 & $28.57 \%$ & Rendah \\
Significance & 6 & $54.54 \%$ & Rendah \\
Virtue & 4 & $57.14 \%$ & Rendah \\
Competence & 6 & $30 \%$ & Rendah \\
\hline
\end{tabular}

\begin{tabular}{lcccc}
\hline \multicolumn{1}{c}{ Aspek } & & \multicolumn{2}{c}{ Post-test } & $\begin{array}{c}\% \\
\end{array}$ \\
& Skor & $\%$ & Sriteria & \\
\hline Power & 10 & $71.42 \%$ & Tinggi & $42.85 \%$ \\
Significance & 10 & $90.90 \%$ & Tinggi & $36.36 \%$ \\
Virtue & 6 & $86 \%$ & Tinggi & $28.57 \%$ \\
Competence & 16 & $80 \%$ & Tinggi & $50 \%$ \\
\hline
\end{tabular}

Berdasarkan grafik tabel 3 terlihat bahwa seluruh aspek self-esteem pada Subjek PR mengalami peningkatan, baik itu skor, persentase perubahan, juga kriterianya. Hasil pengukuran keempat aspek self- esteem pada subjek PR dapat dijelaskan sebagai berikut:

Aspek competence mengalami peningkatan tertinggi sebesar $50 \%$. Skor pretest pada aspek ini 6 yang merupakan kriteria rendah, meningkat menjadi 16 yang masuk pada kategori tinggi.

Aspek power mengalami peningkatansebesar $42.85 \%$. Skor pretest pada aspek ini 4 yang merupakan kriteria rendah, meningkat menjadi 10 yang masuk pada kategori tinggi.

Aspek significance mengalami kenaikan sebesar $36.36 \%$. Skor pretest pada aspek ini 6 yang merupakan kriteria rendah, meningkat menjadi 10 yang masuk pada kategori tinggi. 


\title{
Journal of Psychological Science and Profesion (JPSP)
}

\author{
Vol.1, No.1, Desember 2017
}

E-mail: jpsp@unpad.ac.id

Aspek virtue mengalami kenaikan terrendah, yaitu sebesar $28.57 \%$. Skor pretest pada aspek ini 4 yang merupakan kriteria rendah, meningkat menjadi 6 yang masuk pada kategori tinggi.

\section{Pembahasan Subjek PR}

Hasil dari asesmen awal, subjek PR perempuan 16 tahun memiliki berat badan $75 \mathrm{~kg}$ dan tinggi badan $158 \mathrm{~cm}$ (IMT 30.04). PR sering mendapat perlakuan buruk dari teman-temannya. Teman sekolah sering mengejek, menertawakan, bahkan memberi perintah pada subjek. Perlakuan buruk tersebut membuat subjek menghayati dirinya tidak dicintai (unlovable). Keyakinan negatif ini membuat subjek memandang buruk dirinya. Saat subjek PR dihadapkan pada situasi yang mengancam, subjek secara cepat memprediksi kemungkinan terburuk dan membuat kesimpulan negatif berupa pikiran otomatis negatif. Pikiran yang sering muncul yaitu, "Saya tidak mungkin bisa menolak", "Saya tidak berdaya dan tidak bisa melawan", "Saya tidak menyenangkan", "Tidak ada yang mau berteman dengan saya", "Saya pasti dijadikan leluon di depan keals", "Jika saya salah semakin dijauhi", dan "Saya gendut dan tidak menarik".

Dengan adanya pemikiran negatif mengenai diri tersebut, membuat subjek memiliki self-esteem yang rendah. Rendahnya self-esteem membuat PR tidak memiliki kemampuan dalam beradaptasi dengan lingkungan sehingga perilaku yang ditampilkan pun menjadi maladaptif seperti tidak mahir dalam menjalin pertemanan, pasif dan menurut dalam lingkungan, tertutup pada orang baru, tidak aktif di kelas dan terkadang tidak mengikuti pelajaran olahraga karena takut ditertawakan teman saat renang ataupun lari.

Hasil pengukuran yang dilakukan terhadap subjek PR sebelum dan setelah intervensi menunjukkan terdapat peningkatan derajat selfesteem sebesar $42.31 \%$ (tabel 2). Persentase ini menunjukkan bahwa intervensi CBAT diketahui efektif dalam meningkatkan self-esteem subjek PR. Skor pretest sebesar 21 masuk pada kategori self-esteem rendah, dan pada skor posttest mengalami perubahan menjadi 42 yang masuk pada kategori self-esteem tinggi.

Perubahan tampak juga dari setiap aspek yang mengalami peningkatan skor pada tiap aspek self-esteem. Kenaikan tertinggi yaitu ada pada aspek competence sebesar $50 \%$, aspek power mengalami kenaikan sebesar $42.85 \%$, aspek significance meningkat sebesar $36.36 \%$, sedangkan aspek virtue mengalami kenaikan terrendah, yaitu $28.57 \%$ (tabel 3 ).
Skor pada aspek competence meningkat secara signifikan yaitu sebesar $50 \%$ (tabel 3). Bagi remaja, kesuksesan yang dimiliki tidak hanya mampu memenuhi tuntutan prestasi di sekolah, namun juga kesuksesan dalam kemampuan menghadapi masalah (Coopersmith, 1967). Pada masa remaja, individu dituntut untuk berkompetisi dan menilai diri positif untuk mendapat pengakuan dari teman-teman yang akan mempengaruhi juga terhadap penilaian dirinya. Menurut subjek, perlakuan dari teman sekelas yang selalu menjadikannya bahan ejekan sangat mengganggu aktivitas belajar subjek di sekolah, terlebih hal tersebut dikarenakan tubunya yang besar. Subjek sering tidak mengikuti kegiatan olahraga renang karena takut ditertawakan oleh teman, ia juga sering tidak ikut terlibat dalam pegerjaan tugas kelompok karena teman kelompok yang tidak mau memberikan tugas kepadanya, subjek juga merasa khawatir saat ditanya oleh guru yang membuatnya menjadi tidak bisa menjawab pertanyaan tersebut. Subjek juga menilai dirinya sebagai individu yang kurang mampu menghadapi masalah karena terbiasa diarahkan dan dibantu oleh keluarga atau temanteman dalam penyelesaiannya. Pada intervensi CBAT, sesi Transformation memberikan kesempatan subjek untuk belajar menantang pikiran negatif mengenai diri yang tidak menarik. Hal ini dilakuakan karena subjek merasa tubuhnya yang besar menjadi penyebab ia mengalami masalah akademik di sekolah. Kemudian, subjek diarahkan untuk menanamkan pikiran positif untuk tidak menghiraukan penilaian buruk orang lain kepadanya. Terlebih saat hal tersebut berkaitan dengan prestasi di sekolah yang harus ia selesaikan dengan baik agar mampu menyelesaikan tuntutan penilaian untuk dapat naik kelas. Dengan mengubah pikiran menjadi lebih positif, maka subjek menjadi lebih menerima kondisi tubuhnya yang besar. Selain itu, pada sesi Positive/Negative, membuat subjek merasa bahwa ternyata ia memiliki lebih banyak hal positif di dalam dirinya. Dengan mengetahui hal itu, menguatkan pemikirannya bahwa tubuh yang besar pun masih memiliki hal yang baik dan patut untuk diberi apresiasi. Hasil wawancara dengan subjek setelah sesi intevensi selesai, subjek merasa mampu dibandingkan dengan orang lain dan kepercayaan diri meningkat. Subjek lebih berusaha dalam mengerjakan tugastugas yang diberikan di sekolah. Saat ada tugas kelompok pun, subjek lebih bersikap tidak peduli dengan perilaku teman yang tidak menganggapnya ada, ia berusaha mengerjakan tugas sebaik-baiknya. 


\title{
Journal of Psychological Science and Profesion (JPSP)
}

\author{
Vol.1, No.1, Desember 2017
}

E-mail: jpsp@unpad.ac.id

Aspek power meningkat signifikan sebesar $42.85 \%$ (tabel 3). Kekuatan atau power menunjukan pada adanya penilaian diri mengenai kemampuan seseorang untuk dapat mengatur dan mengontrol tingkah laku dan mendapat pengakuan atas tingkah laku tersebut dari orang lain. Mengembangkan keterampilan sosial dengan menyeimbangkan sikap kepemimpinan dan independent dapat menumbuhkan sikap asertif, semangat dan memiliki keinginan untuk mengeksplorasi (Coopersmith, 1967). Pada kenyataannya, dari hasil asesmen awal didapat data bahwa subjek tidak memiliki hal tersebut. Subjek tidak asertif sehingga tidak mampu mengutarakan pendapatnya kepada orang lain, subjek juga pasif dan menurut pada teman yang sering memberi perintah padanya. Dalam intervensi CBAT ini setiap pertemuan, subjek dipaksa untuk menggali perasaan dan juga mengungkapkan apa yang ingin ia utarakan. Hal ini berdampak positif pada asertivitas subjek. Hal ini sesuai dengan pendapat Landgarten (1981), Seni dapat meningkatkan self-esteem karena dapat meningkatkan asertivitas. Membuat karya seni dapat membantu klien secara bebas mengekspresikan kebutuhan sadar dan tidak sadar melalui media seni dan bahasa non verbal (Dow, 2008). Terapi Seni cocok bagi klien yang memiliki kesulitan verbal dalam mengekspresikan perasaan-perasaannya secara terbuka (Karkou \& Glasman, 2004). Hasil wawancara setelah intervensi, subjek mulai merasa mampu mengatakan hal-hal yang ingin ia utarakan kepada teman-temannya, ia punmampu mengutarakan beberapa ide dan terkadang ide tersebut diterima. Dari data observasi, saat disputing pada sesi Saying No, subjek mengatakan bahwa dirinya menjadi bersemangat saat menggambar orang yang memberikan kekuatan untuknya. Proses disputing ini tampaknya berpengaruh besar, di sekolah subjek PR mulai mampu menolak permintaan dari teman. Berani untuk mengatakan pendapat membuat dirinya memiliki kekuatan tersendiri sehingga penghayatan mengenai aspek power meningkat.

Aspek significance mengalami peningkatan sebesar $36.36 \%$ (tabel 3). Penerimaan dari lingkungan ditandai dengan adanya kehangatan, respon yang baik dari lingkungan dan adanya ketertarikan lingkungan terhadap individu dan lingkungan menyukai individu tersebut sesuai dengan keadaan diri yang sebenarnya. Pengamalan-pengalaman subjek akan diinterpretasi dan dimodifikasi sesuai dengan nilai-nilai dan aspirasi yang dimilikinya. Penghayatan ini berpengaruh terhadap individu dalam menilai dirinya dan lingkungan (Coopersmith, 1967). Subjek PR merasa bahwa orang lain tidak mau berteman dengan dirinya karena tidak menarik dan tidak menyenangkan. Seperti data awal yang didapat, subjek menjadi tidak mahir menjalin hubungan dengan orang lain dan subjek hanya memiliki sedikit teman. Pada sesi Who Smiled at Me, subjek telah mampu mengubah pikiran negatifnya. Subjek PR sudah mulai memberanikan diri untuk memulai pembicaraan dengan teman sekelas dengan perasaan nyaman. Hal tersebut membuatnya senang karena selama ini pikiran negatif mengenai orang lain yang tidak mau berbincang atau menerima dirinya, ternyata tidak semuanya benar. Beberapa teman memberikan respon positif saat subjek PR memulai perbincangan terlebih dahulu. Dengan adanya perubahan tersebut, subjek PR merasa lebih diterima oleh teman-temannya sehingga penghayatan mengenai aspek significance mengalami peningkatan.

Aspek virtue mengalami peningkatan yang kurang signifikan sebesar $28.57 \%$ (tabel 3). Virtue berhubungan dengan merasa bahwa dirinya merupakan orang yang baik sesuai norma yang berlaku. Subjek PR merasa bahwa dirinya merupakan orang yang baik, sehingga persentase awal pun sudah cukup tinggi $(57.14 \%)$ walaupun berada pada kategori rendah. Namun subjek merupakan individu yang sangat mudah dipengaruhi oleh perasaan dalam bertindak. Jika subjek PR sedang merasa sedih atau kesal, maka semua aktivitas menjadi terhambat dan hal tersebut membuat subjek merasa dirinya kurang baik dalam mengelola emosi. Pada sesi Counting blessing, subjek melakukan eksplorasi mengenai anugerah dari Tuhan yang ia miliki, subjek menjadi lebih sadar bahwa dengan bersyukur dan tidak berfokus pada masalah yang dihadapi membuatnya lebih bahagia. Hal ini membuat penghayatan mengenai aspek virtue meningkat.

Pembinaan rapport yang baik dapat meningkatkan kepercayaan partisipan terhadap terapis. Interaksi yang baik antara terapis biasanya berbanding lurus dengan hasil penanganan (Westbrook, Kennerley, \& Kirk, 2007). Klien biasanya memiliki kesempatan yang besar untuk berhasil dalam penanganan, menawarkan saran mengenai treatment, dapat berinteraksi dengan hangat dan mempercayai terapis (Westbrook, Kennerley, \& Kirk, 2007). Baik subjek PR secara umum menunjukkan sikap yang ramah, hangat, antusias, dan hangat kepada peneliti. Pada awalnya, subjek PR merupakan orang yang tertutup dan tidak mudah 


\section{Journal of Psychological Science and Profesion (JPSP)}

Vol.1, No.1, Desember 2017

E-mail: jpsp@unpad.ac.id

menceritakan dirinya kepada orang yang baru ia kenal. Namun setelah beberapa kali pertemuan, kesan tersebut berubah. Subjek mampu bercerita banyak hal dan ia sudah mulai mampu membuka dirinya dengan peneliti. Bahkan setelah tiga kali sesi intervensi, terkadang saat pertama bertemu untuk melakukan intervensi, subjek ingin bercerita mengenai kegiatan dan perasaannya baik itu yang mengganggu ataupun yang menyenangkan. Jika dihubungkan dengan self-esteem, dapat dikatakan bahwa memang benar relasi terapisklien berkontribusi terhadap peningkatan selfesteem yang dialami oleh subjek. Salah satu strategi untuk meningkatkan self-esteem adalah melalui penerimaa, kepedulian, dan dukungan sosial (Mruk, 2006). Dengan melakukan intervensi, terapis pada dasarnya sudah melakukan penerimaan terhadap klien karena terapis mau mendengarkan dan membantu klien mengatasi permasalahannya. Memperlakukan individu yang memiliki permasalahan self-esteem dengan penghargaan akan menjadi pengalaman teurapetik bagi individu tersebut, karena biasanya mereka sering mendapatkan penolakan (Mruk, 2006). Hal ini menjadi alasan subjek menjadi berubah menjadi lebih terbuka.

\section{Subjek AP}

Tabel 4 .Perubahan Skor Aspek Self-esteem Subjek AP

\begin{tabular}{lccl}
\hline \multicolumn{1}{c}{ Aspek } & & \multicolumn{2}{c}{ Pre-test } \\
& Skor & $\%$ & Kriteria \\
\hline Power & 6 & $42.85 \%$ & Rendah \\
Significance & 5 & $45.45 \%$ & Rendah \\
Virtue & 2 & $28.57 \%$ & Rendah \\
Competence & 8 & $40 \%$ & Rendah \\
\hline
\end{tabular}

\begin{tabular}{lcccc}
\hline \multicolumn{1}{c}{ Aspek } & & \multicolumn{2}{c}{ Post-test } & $\begin{array}{c}\% \\
\text { Peruba } \\
\text { han }\end{array}$ \\
& Skor & $\%$ & Kriteria & \\
\hline Power & 11 & $78.57 \%$ & Tinggi & $35.72 \%$ \\
Significance & 10 & $90.90 \%$ & Tinggi & $45.45 \%$ \\
Virtue & 6 & $85.71 \%$ & Tinggi & $57.14 \%$ \\
Competence & 14 & $70 \%$ & Tinggi & $30 \%$ \\
\hline
\end{tabular}

Berdasarkan tabel 4, terlihat bahwa seluruh aspek self-esteem pada Subjek AP mengalami peningkatan, baik itu skor, persentase perubahan, maupun kriterianya. Hasil pengukuran keempat aspek self-esteem pada subjek AP dapat dijelaskan sebagai berikut:

Aspek virtue mengalami kenaikan terrendah, yaitu sebesar $57.14 \%$. Skor pretest pada aspek ini 2 yang merupakan kriteria rendah, meningkat menjadi 6 yang masuk pada kategori tinggi.
Aspek significance mengalami kenaikan sebesar $45.45 \%$. Skor pretest pada aspek ini 5 yang merupakan kriteria rendah, meningkat menjadi 10 yang masuk pada kategori tinggi.

Aspek power mengalami peningkatansebesar $35.72 \%$. Skor pretest pada aspek ini 6 yang merupakan kriteria rendah, meningkat menjadi 11 yang masuk pada kategori tinggi.

Aspek competence mengalami peninggatakan tertinggi sebesar 50\%. Skor pretest pada aspek ini 8 yang merupakan kriteria rendah, meningkat menjadi 14 yang masuk pada kategori tinggi.

\section{Pembahasan Subjek AP}

Hasil dari asesmen awal, subjek AP perempuan 15 tahun dengan berat badan $93 \mathrm{~kg}$ dan tinggi badan $173 \mathrm{~cm}$ (IMT 31,1). Sama seperti subjek PR, subjek AP juga mendapat perlakuan buruk dari teman-temannya. Teman sekolah sering mengejek dan menertawakan subjek. Perlakuan buruk tersebut membuat subjek menghayati dirinya tidak dicintai (unlovable). Keyakinan negatif ini membuat subjek merasa buruk mengenai dirinya. saat subjek AP dihadapkan pada situasi yang mengancam, subjek secara cepat memprediksi kemungkinan terburuk dan membuat kesimpulan negatif berupa pikiran otomatis negatif. Pikiran yan sering muncul yaitu, "Saya tidak tidak bisa melawan", "saya tidak diterima teman-teman", "saya tidak dianggap ada oleh teman", "saya pasti dijadikan leluon di depan keals", dan "saya bukan orang yang baik".

Dengan adanya pemikiran negatif mengenai diri tersebut, membuat subjek memiliki self-esteem yang rendah. Rendahnya self-esteem membuat AP tidak memiliki kemampuan dalam beradaptasi dengan lingkungan sehingga perilaku yang ditampilkan pun menjadi mal-adaptif seperti tidak mahir dalam menjalin pertemanan dan pasif dalam lingkungan, tidak asertif, tertutup pada orang baru, sering menyendiri, tidak aktif di kelas, tidak semangat pergi sekolah, mudah marah, sinis terhadap orang lain, sering merasa iri pada orang lain.

Perilaku tersebut mengindikasikan selfesteem subjek yang rendah dan tampak dari hasil skor pretest (tabel 2). Namun setelah diberikan intervensi CBAT, skor self-esteem subjek mengalami peningkatan. Hasil pengukuran yang dilakukan terhadap subjek AP sebelum dan setelah intervensi menunjukkan terdapat peningkatan derajat self-esteem sebesar $38.46 \%$ (tabel 2). Skor pretest sebesar 21 yang masuk pada kategori self-esteem rendah dan pada skor 


\title{
Journal of Psychological Science and Profesion (JPSP)
}

\author{
Vol.1, No.1, Desember 2017
}

E-mail: jpsp@unpad.ac.id

posttest mengalami perubahan menjadi 41 yang masuk pada kategori self-esteem tinggi (tabel 2).

Perubahan tampak juga dari setiap aspek yang mengalami peningkatan skor pada tiap aspek self-esteem. Kenaikan tertinggi yaitu ada pada aspek virtue, sebesar $57.14 \%$, aspek significance mengalami kenaikan sebesar $45.45 \%$, aspek power meningkat sebesar $35.72 \%$, sedangkan aspek competence mengalami kenaikan terrendah, yaitu $30 \%$ (tabel 4 ).

Penghayatan mengenai aspek virtue meningkat signifikan sebesar $57.14 \%$ (tabel 4). Merasa diri baik sangat penting bagi kebanyakan orang. Virtue juga berkaitan dengan moral, standar etika dan prinsip spiritual (Coopersmith, 1967). Pada awalnya subjek AP merasa bahwa dirinya bukanlah orang yang baik karena dirinya dikendalikan oleh emosi negatif sehingga sering melakukan agresi verbal dan melempar barang saat merasa kesal terhadap perlakuan teman yang tidak menyenangkan. Subjek merasa tidak mampu mengendalikan emosi negatifnya sehingga merasa dirinya tidak baik. Hasil observasi menunjukkan bahwa pada asesmen dan beberapa sesi intervensi, subjek AP masih melontarkan agresi verbal. Namun selama tiga sesi terakhir, terlihat perubahan yaitu subjek tidak mengeluarkan agresi verbal sama sekali. Pada intervensi ini, mulai dari proses asesmen awal juga saat intervensi CBAT, media gambar dipakai untuk eksplorasi masalah, perasaan, dan juga untuk mengubah pikiran negatif yang dimiliki subjek. Subjek memiliki kemampuan menggambar yang baik sehingga membuat dirinya lebih mampu menuangkan perasaannya dengan cara yang mudah dan aman. Dikatakan dengan mudah karena subjek mampu menggambarkan situasi emosi ke dalam gambar dengan sangat jelas. Menurut Buchalter (2009), menggambar memberikan kesempatan pada subjek untuk mengkomunikasikan perasaan, perhatian, masalah, keinginan, harapan, dan pikiran dengan cara-cara yang tidak mengancam. Dengan adanya gambaran yang jelas yang subjek AP buat, hal ini pun memudahkan subjek memahami perasaan dan penyebab dari perasaan itu terjadi. Hal ini sejalan dengan hasil penelitian sebelumnya yaitu, dengan membuat suatu karya seni juga dapat membuat masalahyang dihadapi klien menjadi kongkrit dan nyata sehingga akan lebih mudah dieksplorasi, baik secara verbal maupun non-verbal (Rozum \& Malchiodi, 2003). Dengan begitu, ia mampu untuk mengontrol perilaku dan tutur katanya saat ia sedang menghadapi situasi yang menimbulkan kemarahan. Dari hasil wawancara setelah intervensi selesai, subjek merasa mulai mampu mengatakan hal-hal yang ingin ia utarakan ataupun penyebab dari kemarahan yang ia rasakan kepada teman-temannya. Hal ini menyebabkan penghayatan mengenai dirinya yang baik pun meningkat.

Aspek significance meningkat cukup signifikan sebesar $45.45 \%$ (tabel 4 ). Penerimaan dari lingkungan ditandai dengan adanya kehangatan, respon yang baik dari lingkungan dan adanya ketertarikan lingkungan terhadap individu dan lingkungan menyukai individu tersebut sesuai dengan keadaan diri yang sebenarnya. Hasil asesmen awal, menurut subjek perlakuan negatif dari lingkungan teman sekolah membuat subjek merasa dirinya tidak disenangi dan tidak diterima oleh lingkungan. Subjek pun tidak memiliki kemampuan untuk menjalin pertemanan dengan mudah. Pada intervensi CBAT, restrukturisasi kognitif terhadap pemikiran negatif tersebut diubah dengan pemberian sesi Relationship dan Who Smiled at Me. Pada sesi Relationship, subjek mendapatkan insight bahwa memiliki sedikit sahabat tidak menjadi masalah, asalkan sahabat yang ada mampu menerima kekurangan dan membuat dirinya nyaman. Selain itu, pada sesi Who Smiled at Me pemikiran bahwa tidak ada yang mau berteman dengan subjek didispute. Pemaknaan dirinya mengenai lingkungan berubah, yaitu lingkungan tidaklah selalu berperilaku buruk terhadapnya, sehingga subjek tidak perlu lagi menghiraukan penilaian dari lingkungan. Hal ini berdampak positif pada perasaan dan perilaku subjek. la menjadi lebih nyaman saat berada di lingkungan sosial, terutama saat harus menampilkan dirinya dan rasa cemas yang dialami berkurang. Dengan adanya perubahan tersebut, subjek AP merasa lebih diterima oleh lingkungan sehingga penghayatan mengenai aspek significance meningkat.

Aspek power meningkat sebesar $35.72 \%$ (tabel 4). Power menunjukan pada adanya penilaian diri mengenai kemampuan seseorang untuk dapat mengatur dan mengontrol tingkah laku diri sendiri dan mendapat pengakuan atas tingkah laku tersebut dari orang lain. Pengakuan dari orang lain memberikan apresiasi terhadap dirinya. Mengembangkan keterampilan sosial dengan menyeimbangkan sikap kepemimpinan dan independen dapat menumbuhkan sikap asertif, semangat dan keinginan untuk bereksplorasi (Coopersmith, 1967). Selama ini, subjek AP merasa bahwa dirinya masih kurang memiliki kemampuan tersebut. Terlebih dengan adanya perilaku buruk dari lingkungan, 


\title{
Journal of Psychological Science and Profesion (JPSP)
}

\author{
Vol.1, No.1, Desember 2017
}

E-mail: jpsp@unpad.ac.id

membuatnya menjadi individu yang pasif bahkan ia pun menjadi tidak memiliki daya untuk mengontrol dirinya sendiri. Pada sesi Stop Sign subjek melakuakan eksplorasi mengenai hal-hal yang menghambat dirinya dan mencari cara untuk mengatasinya. Sesi ini memberikan dampak positif untuk diri subjek, ia merasa lebih dapat mengontrol dirinya sendiri terlebih saat dihadapkan dengan pilihan ataupun masalah. Sedangkan pada sesi Saying No, dengan berkata "Tidak" terkadang merupakan hal yang positif, terutama jika dihubungkan dengan aspek power dalam self-esteem. Dengan berkata "Tidak", berarti ada usaha dalam diri subjek untuk mampu melawan penindasan dan mengontrol perilaku orang lain terhadap dirinya. Namun, perlakuan buruk dari teman-teman yang masih dirasakan membuat subjek belum berani untuk memberikan perlawanan dan mempertahankan dirinya. Hal ini yang membuat peningkatan aspek power masih kurang signifikan.

Aspek competence meningkat sebesar $30 \%$ (tabel 4). Pada masa ini remaja dituntut untuk berkompetisi dan menilai diri positif untuk mendapat penghargaan dari teman-teman yang akan mempengaruhi juga terhadap penilaian dirinya. data yang didapat dari asesmen awal, perlakuan dari teman sekelas yang selalu menjadikannya bahan ejekan sangat mengganggu aktivitas belajarnya di sekolah, terlebih hal tersebut dikarenakan tubunya yang besar. Subjek menjadi takut untuk maju ke depan kelas saat ditunjuk oleh guru dan tidak bersemangat dalam mengikuti kegiatan di sekolah. Pada intervensi CBAT, sesi Transformation memberikan kesempatan subjek untuk belajar menantang pikiran negatif mengenai diri yang tidak menarik. Hal ini dilakuakan karena subjek merasa tubuhnya yang besar menjadi penyebab ia mengalami masalah akademik di sekolah. Dengan mengubah pikiran menjadi lebih positif, maka subjek menjadi lebih menerima kondisi tubuhnya yang besar. Eksplorasi mengenai kekuatan yang dimiliki di sesi Positive/Negative membuat subjek menyadari akan kelebihan di dalam dirinya. Pada sesi ini, subjek menjelaskan gambaran yang dibuatnya menggunakan Bahasa Inggris dan Jepang. Subjek juga menyadari bahwa dirinya memiliki kemampuan menari, dan pada sesi enam ia memperlihatkan video tugas sekolah yang menampilkan dirinya sedang menari. Hal ini menguatkan bahwa tubuh yang besar pun masih memiliki hal yang baik dan patut untuk diberi apresiasi. Ternyata subjek merasa nyaman setelah mengekspresikan dirinya. Dari data wawancara setelah sesi intervensi selesai, subjek mengatakan bahwa dirinya masuk dalam komunitas cover dance Korea dan ia merasa dirinya mendapatkan penghargaan dari komunitas tersebut sehingga subjek mampu menampilkan kemampuan diri secara lebih. Namun dalam lingkungan sekolah subjek tidak pernah mendapatkan penghargaan atas kemampuan yang ia miliki. Padahal subjek memiliki banyak kelebihan, salah satunya menggambar dan bermain voli. Kelebihan tersebut tidak pernah diberi tanggapan positif oleh teman-temannya, bahkan ada teman yang mengejeknya saat sedang melakukan olahraga voli. Perilaku dari lingkungan yang sering menjadikannya lelucon, membuat subjek masih merasa terganggu. Walaupun begitu, subjek AP masih tetap berusaha mengatasinya dan berusaha untuk tidak menghiraukan apa yang teman-teman katakan kepadanya. la pun masih selalu berlatih voli, mengikuti lomba gambar, dan mulai mau maju ke depan kelas saat ditunjuk oleh guru. Oleh sebab itu, penghayatan mengenai aspek competence tetap meningkat walaupun kurang signifikan.

\section{SIMPULAN}

Cognitive Behavioral Art Therapy (CBAT) cukup efektif dalam meningkatkan derajat self-esteem remaja obesitas. Kedua subjek mengalami perubahan self-esteem dari kategori rendah menjadi kategori tinggi. Peningkatan ini terjadi karena bentuk kegiatan pada intervensi CBAT ini dirancang khusus untuk remaja obesitas.

Di antara aspek-aspek self-esteem, aspek competence mengalami kenaikan tertinggi pada subjek 1 , yaitu sebesar $50 \%$ dan aspek virtue mengalami kenaikan tertinggi pada subjek 2 , yaitu sebesar $57.14 \%$. Ketika cara berpikir subjek diubah menjadi lebih positif maka berdampak pada perubahan penilaian diri yang menjadi lebih positif pula.

Sedangkan aspek yang perubahannya paling rendah adalah aspek virtue sebesar $28.57 \%$ pada subjek PR dan aspek competence $30 \%$ pada subjek AP. Namun kedua aspek ini tetap mengalami perubahan kategori, yaitu berubah dari kategori rendah menjadi kategori tinggi. Sehingga penilaian subjek atas dirinya dan kemampuan yang dimiliki pun berubah menjadi lebih positif.

Peneliti juga dapat menyarankan beberapa hal terkait penelitian ini, yaitu perlunya mempertimbangkan untuk melakukan intervensi hanya satu kali saja dalam seminggu, untuk menghindari faktor kelelahan. Selain itu, perlu 


\section{Journal of Psychological Science and Profesion (JPSP)}

Vol.1, No.1, Desember 2017

E-mail: jpsp@unpad.ac.id

dipertimbangkan pula untuk tidak mengizinkan subjek penelitian menyalakan ponsel. Lebih baik ponsel dimatikan agar subjek dapat fokus ketika melakukan intervensi.

\section{UCAPAN TERIMAKASIH}

Terimakasih kepada Ardhana Riswarie, M.A., AthR sebagai supervisor Art Therapy dan kepada Saktiyono B.P., M.Psi., Psikolog sebagai supervisor Cognitive Behavior Therapy.

\section{DAFTAR PUSTAKA}

Alavinezhad, R., Mousavi, M., \& Sohrabi, N. (2014). Effects of Art therapy on Anger and Self-Esteem In Aggressive. Procedia Social and Behavioral Sciences, 113, 111-117

Kemenkes Rl. (2013). Riset Kesehatan Dasar; RISKESDAS. Jakarta: Balitbang Kemenkes $\mathrm{RI}$

Buchalter, Susan. (2009). Art Therapy Techniques and Applications. London :Jessica Kingsley Publishers.

Cash, T.F. \& Pruzinsky, T. eds. (2002). Body image: A handbook of theory, research, and clinical practice. New York: Guilford Press.

Clark, D. A., \& Beck, A. T. (2010). Cognitive Theory and Therapy of Anxiety and Depression: Convergence with Neurobiological Findings. Trends in Cognitive Science, 14(9), 418-24.

Cohen, N.H. (2006). Art therapy and clinical neuroscience in action. GAINS Community Newsletter: Spring2006, 10- 12

Coopersmith, Stanley. (1967). The Antecedent Of Self Esteem. San Fransisco : Freman Press

Dow, Georgia. (2008). Increasing Self Esteem through Art Therapy. A Research Paper in The Departement of Creative Art Therapies. Montreal: Concordia University

Emler, Nicholas. (2001). Self Esteem: The Cost and Causes of Low Self Worth. York: Published for Joseph Rowntree Foundation by YPS

Fennell, Melanie J.(1998). Cognintive Therapy in the Treatment of Low Self Esteem. Advances in Psychiatric Treatment. Journal of Psychology

Fennell , M. \& Jenkins, H. (2004). Low SelfEsteem. In J. Bennett-Levy, G. Butler, M.Fennell et al (Eds), Oxford Guide to Behavioural Experiments in Cognitive Therapy. Oxford: Oxford Medical Publications.
Karkou, V. \& Glasman, J. (2004). Arts, Education and society: the Role of The Arts in Promoting the Emotional Well Being and Social Inclysion of Young People. 'Support for Learning'

Kernis, Michael H.(2006). Toward a Conceprualization of Optimalization Self Esteem. Taylor \& Francis, Ltd:

Langarten, H.B. (1981). Clinical Art Therapy: A Comprehensive Guide. New York: Brunner/Mazel.

Malchiodi, Cathy A. (2003). Handbook of Art Therapy. New York: Guildford Press

Mruk, Christopher. (2006). Self-esteem Research, Theory, and Practice: Toward a positive psychology of self-esteem (3rd Ed). New York: Springer.

Oktavianti, R., Novia, N.S., \& Rahmawati, R., (2008). Self Esteem. Jurusan Psikologi Pendidikan Dan Bimbingan Fakultas IImu Pendidikan Universitas Pendidikan Indonesia, Bandung.

Oster, Gerrald. \& Crone, Patricia Gould. (2004). Using Drawing in Assessment and Therapy: A Guide for Mental Health. New York: BrunnerRoutledge

Psunder, M. (2010). The Idenntification of teasing among students as an indispensable step towards reducing verbal aggression in school. Journal of Psychology, 36, 217. Doi: 10.1080/03055690903162192

Rubin, Judith Aaron. (2001). Approaches to Art Therapy. London: Taylor \& Francis Ltd

Sarafino, J.W. (2002). Health Psychology: Biopsychology Social Interactions ( $4^{\text {th }}$ edition). New York: John Willey \& Sons.

Scachter, S. (1971). Emotion obesity, and crime. New York: Academic Press

Siregar, A. R. (2006). Harga Diri Remaja Obesitas. Medan: USU Repository

Taylor, N.L. (2011). 'Guys, she's humongous!' : A gender and weight based teasing in adolescence. Journal of Adolescence research, 26, 178-199. Doi: $10.1177 / 0743558410371128$

Westbrook, D., Kennerley, H. \& Kirk, J. (2007). An Introduction to Cognitive Behavioural Therapy: Skill \& Applications. Great Britain: Sage Publication

\section{Sumber Internet}

(http://www.republika.co.id/berita/gaya-hidup/infosehat/13/03/04/mi543o-ini-diapenyebab-meningkatnya-angkaobesitas, 05 Maret 2013, diakses 21 September 2014) 


\section{Journal of Psychological Science and Profesion (JPSP)}

Vol.1, No.1, Desember 2017

E-mail: jpsp@unpad.ac.id

(http://intisari-online.com/Techno/Science/Fakta-

Tentang-Obesitas-Dan-Kegemukan, 24

Februari 2012, diakses 21 September 2016)

(http://www.bbc.com/indonesia/majalah/2014/05/1

40529 iptek indonesia obesitas, 19

Mei 2014, diakses tgl 05 September

2016) 